nificant part in ion transport and other processes associated with membrane function ${ }^{12,13}$. Tewari and Bourne ${ }^{15}$ have also suggested such a role of the acid phosphatase in the synapses of the cerebral cortex of rat. Thus it seems likely that the lysosomes, after originating from the Golgi apparatus in the perinuclear zone, migrate to dendrites to play their parts in ion transport and other phenomena like pinocytosis, with the acid phosphatase mediating the processes.

\section{P. P. Sood}

H. B. Tewari

Department of Zoology,

University of Udaipur,

Udaipur (Rajasthan), India.

Received January 23; revised April 11, 1967.

${ }^{1}$ Novikoff, A. B., in The Cell, Biochemistry, Physiology, Morphology (edit. by Brachet, J., and Mirsky, E.), 2 (Academic Press, New Xork, 1961)

"Hyden, H., in The Cell, Biochemistry, Physiology, Morphology (edit. by

Brachet, J., and Mirsky, E.), 4. Pt. 1(Academic Press, New York, 1960).

s Covell, W. P., and Scott, G. H., Anat. Rec., 38, 377 (1928).

4 roenig, H., Nature, 195, 782 (1962).

- Eranko, O., Acta Physiol. Scand., 24, 1 (1951).

' Kokko, A., Acta Physiol. Scand., 66, suppl., 1 (1965).

"Pearse, A. G. E., Histochemistry, Theoretical and Applied (J. and A. Churchill, London, 1961).

"Singer M., in Progress in Brain Research, 13, 228 (1964).

"Bodian, D., Proc. US Nat. Acad. Sci., 53, 418 (1965).

"Gray, E. G., in Electron Microscopic Anatomy (edit. by Kurtz, S. M.), 369 (Academic Press, New York, 1964)

11 Pappas, G. D., and Purpura, D. P., Exp. Neurol., 4, 507 (1961).

${ }^{12}$ Bogoch, S., Neurology, 10, 439 (1960).

${ }^{13}$ McIlwain, H., Biochem. J., 78, 24 (1961).

14 Pope, A., et. al., J. Neurophysiol., 19, 259 (1956)

${ }^{16}$ Tewari, H. B., and Bourne, G. H., J. Histochem. Cytochem., 11, 116 (1963).

\section{RADIOBIOLOGY}

\section{Cytotoxicity of Carbohydrates Heavily Irradiated in Solution}

Heaviry irradiated solutions of carbohydrates have been shown to influence the growth of cultures of bacteria ${ }^{1}$, and plant $^{2}$ and mammalian cells ${ }^{3}$, as well as producing chromosomal abnormalities in mammalian cells ${ }^{4}$. Steward et al. ${ }^{5}$ have recently described the isolation from irradiated sucrose solution of a salt of formic acid which was characterized as sodium formate, and was shown to suppress the growth of carrot phloem explants.

In our earlier work on the effect of autoclaved and irradiated carbohydrate solutions on mammalian cells in tissue culture ${ }^{3,6}$, we concluded that the compound most likely to account for the persistent toxicity of irradiated solutions was the radiolytic product glyoxal. It was shown that the gross cytotoxicity of irradiated carbohydrate solutions was closely reproduced in our experimental system by a solution of glyoxal equivalent in concentration to the glyoxal present in the appropriate irradiated carbohydrate solution.

The presence of formaldehyde in irradiated carbohydrate solutions is known from the work of Phillips? but it is unlikely that it is itself cytotoxic for the reasons discussed in our earlier paper ${ }^{3}$. The recent observation of Steward et al. ${ }^{5}$ suggests that the oxidation of formaldehyde to formic acid, which might occur during irradiation or in the culture medium, results in the development of cytotoxicity. If this were so, glyoxal might similarly be converted to oxalic acid which must then be suspected as a potential cytotoxic agent. Because oxalic and formic acids are interconvertible, at least by chemical means, the gross effect of irradiated carbohydrate solutions might be accounted for by the system

\section{formaldehyde $\rightarrow$ formic acid $\rightleftharpoons$ oxalic acid $\leftrightarrow$ glyoxal}

This hypothesis was tested by the addition of formic and oxalic acids (as their sodium salts), glyoxal, or irradiated glucose solutions to the culture medium in which strain $L$ mouse fibroblasts are grown. The culture techniques have been described in detail in our earlier article ${ }^{3}$; the cells are grown attached to the glass surface of sealed bottles, collected by trypsinization, and the total growth after incubation at $37^{\circ} \mathrm{C}$ for 7 days counted electronically. The results are shown in Table 1, expressed as a percentage of growth in control cultures incubated simultaneously. Sodium formate exerts no cytotoxic effect, even at a concentration ten times higher than that shown by Steward et al. ${ }^{5}$ to be present in solutions of irradiated carbohydrates. Sodium oxalate is also much less cytotoxic than glyoxal. It can be calculated that, even if all the glucose transformed during irradiation with 2.5 Mrads were to appear as oxalic acid, the amount of acid produced would still not account for the observed cytotoxicity of the irradiated glucose solution.

Table 1. GRowTH OF STRAIN $L$ MOUSE fIBRobLASTS

Ordinary growth medium plus: $\quad \begin{gathered}\text { Percentage of } \\ \text { control growth }\end{gathered}$ Ref.

Autoclaved distilled water (control)
1 per cent solution, dextrose, B.P., filter-
sterilized
1 per cent solution, dextrose, B.P., irradi-
ated, $2 \cdot 5$ Mrads
1 per cent solution, dextrose, B.P., irradi-
ated, $2 \cdot 5$ Mrads, stored for two years
Glyoxal, $0 \cdot 0073 \mathrm{mg} / \mathrm{ml}$.
$0 \cdot 022 \mathrm{mg} / \mathrm{ml}$.
$0 \cdot 073 \mathrm{mg} / \mathrm{ml}$.
$0 \cdot 22 \mathrm{mg} / \mathrm{ml}$.
$0 \cdot 73 \mathrm{mg} / \mathrm{ml}$.
Sodium formate, reagent grade
$0 \cdot 0017 \mathrm{mg} / \mathrm{ml}$.
$0 \cdot 017 \mathrm{mg} / \mathrm{ml}$.
$0 \cdot 17 \mathrm{mg} / \mathrm{ml}$.
Sodium $0 \times a l a t e, ~ ' A n a l a R '$
$0 \cdot 022 \mathrm{mg} / \mathrm{ml}$.
$0 \cdot 22 \mathrm{mg} / \mathrm{ml}$.
$2.2 \mathrm{mg} / \mathrm{ml}$.$$
\text { in } 7 \text { days }
$$$$
100 \quad 3 \text { and present }
$$$$
1043 \text { experiments }
$$$$
1 \cdot 3
$$$$
\text { 2.2 Present }
$$

100
71
34
$1 \cdot 4$
$0 \cdot 8$

\begin{tabular}{|c|c|c|}
\hline 106 & \multicolumn{2}{|c|}{$\begin{array}{l}\text { Present } \\
\text { experiments }\end{array}$} \\
\hline $\begin{array}{l}102 \\
109\end{array}$ & ", & ", \\
\hline $\begin{array}{l}79 \\
37\end{array}$ & " & ", \\
\hline $2 \cdot 2$ & ", & ", \\
\hline
\end{tabular}

These results indicate that the eytotoxicity of the formate salt which has been demonstrated by Steward et $a l .{ }^{5}$ is unlikely to be duplicated by the combined formic acid (which would appear as sodium formate in culture media for mammalian cells at $p \mathrm{H} 7 \cdot 0-7 \cdot 2$ ) produced by radiolysis of carbohydrates in solution. This is also corroborated by the fact that labelled sodium formate is a common starting material used in the biological synthesis of a variety of compounds labelled with carbon-14. In these circumstances, oxidative processes involving the formation of formic and oxalic acids from formaldehyde and glyoxal cannot be expected to contribute to the cytotoxicity of heavily irradiated carbohydrate solutions.

Finally, the 1 per cent solution of glucose irradiated with $2 \cdot 5$ Mrads, which has been used in these studies, has been shown to retain its eytotoxicity for more than 2 years after irradiation.

The work of the Radiobiology Laboratory, Churchill Hospital, Oxford, is supported by a grant from the Medical Research Council.

\section{P. R. Hills}

UK Atomic Energy Authority Research Group, Isotope Research Division,

Atomic Energy Research Establishment,

Wantage Research Laboratory,

Wantage, Berkshire.

Radiobiology Laboratory,

Radiotherapy Department,

Churchill Hospital, Oxford.

Received April 4, 1967.

1 Molin, N., and Ehrenberg, L., Intern. J. Rad. Biol., 8, 223 (1964).

2 Holsten, R. D., Sugii, M., and Steward, F. C., Nature, 208, 850 (1965).

${ }^{3}$ Berry, R. J., Hills, P. R., and Trillwood, W., Intern. J. Rad. Biol., 9, 559 (1965).

4 Shaw, M. W. and Hayes, F., Noture, 211, 1254 (1966).

${ }^{5}$ Steward, F. C., Holsten, R. D., and Sugii, M., Nature, 213, 178 (1967).

- Berry, R. J., Hills, P. R., and Trillwood, W., Brit. Med. J., ii, 124 (1964).

? Phillips, G. O., Adv. Carbohydrate Chem.,16, 13 (1961). 